\title{
Binge Drinking and Metabolic Syndrome
}

\section{Letter}

\author{
Sim Sai Tin*, Viroj Wiwanitkit ${ }^{1}$
}

Department of Medical Science, Medical Center, Shantou; ${ }^{1}$ Visiting Professor, Department of Tropical Medicine, Hainan Medical University, Haikou, China

\section{Dear Editor,}

We would like to discuss the topic 'binge drinking and metabolic syndrome. ${ }^{11}$ Im et al. ${ }^{1)}$ noted for "a positive relationship between frequency of binge drinking and metabolic syndrome in adult men.” In an animal model study, the effect of binge drinking on insulin metabolism can be seen. Lindtner et al. ${ }^{2)}$ reported that "binge drinking induces systemic insulin resistance by impairing hypothalamic insulin action and that this effect can be prevented by inhibition of brain protein tyrosine phosphatase 1B." However, an important consideration of the present report by $\mathrm{Im}$ et al. ${ }^{1)}$ is the confounding factor that can lead to the problem of metabolic syndrome. The drinker usually demonstrates other concomitant risk behaviors such as smoking, ${ }^{3)}$ hence, it is difficult to conclude the effect of binge drinking without consideration of other factors. Finally, it should be noted that measurement of "binge drinking" should be discussed. Normally, the problem of reliability and accuracy of determination is common. Matano et al. ${ }^{4)}$ noted that "accurate methods for assessing binge drinking appear to be by directly asking for the largest number of drinks consumed in a single drinking session.”

Yours Sincerely

$$
\begin{aligned}
& { }^{*} \text { Corresponding Author: Sim Sai Tin } \\
& \text { Tel: }+86648286000 \\
& \text { E-mail: simsaitin@gmail.com }
\end{aligned}
$$

Korean Journal of Family Medicine

Copyright (C) 2014 The Korean Academy of Family Medicine

(c) This is an open-access article distributed under the terms of the Creative Commons Attribution Non-Commercial License (http://creativecommons.org/licenses/by-nc/3.0) which permits unrestricted noncommercial use, distribution, and reproduction in any medium, provided the original work is properly cited.

\section{CONFLICT OF INTEREST}

No potential conflict of interest relevant to this article was reported.

\section{REFERENCES}

1. Im HJ, Park SM, Choi JH, Choi EJ. Binge drinking and its relation to metabolic syndrome in korean adult men. Korean J Fam Med 2014;35:173-81.

2. Lindtner C, Scherer T, Zielinski E, Filatova N, Fasshauer M, Tonks NK, et al. Binge drinking induces whole-body insulin resistance by impairing hypothalamic insulin action. Sci Transl Med 2013;5:170ra14.

3. Ling PM, Neilands TB, Glantz SA. Young adult smoking behavior: a national survey. Am J Prev Med 2009;36:389-94. e2.

4. Matano RA, Koopman C, Wanat SF, Whitsell SD, Borggrefe A, Westrup D. Assessment of binge drinking of alcohol in highly educated employees. Addict Behav 2003;28:1299-310. 